\title{
ПРОГНОЗУВАННЯ СТУПЕНЮ НЕБЕЗПЕЧНОСТІ ЗАБРУДНЕННЯ ГРУНТУ, ПІДЗЕМНИХ ТА ПОВЕРХНЕВИХ ВОДОДЖЕРЕЛ ПЕСТИЦИДАМИ 3 КЛАСІВ ТРІАЗОЛОНІВ, ТРИКЕТОНІВ ТА КАРБОКСАМІДІВ ЗАЛЕЖНО ВІД ГРУНТОВО-КЛІМАТИЧНИХ УМОВ
}

\section{Мартіянова Юлія, Коршун Марія}

Кафедра гігієни та екології № 3, НМУ імені О.О. Богомольця, м. Київ, Україна

\begin{abstract}
Анотація. Домінуюче місие в боротьбі зі шкідниками, бур'янами та хворобами рослин займають хімічні засоби захисту, використання яких забезпечує отримання високих врожаїв сільськогосподарських культур. Водночас, поряд з високим економічним ефектом, існує потенційна небезпека широкого застосування пестищидів, зумовлена їх токсичністю для живих організмів, зокрема ссавиів, та здатністю накопичуватися у трунті, мігрувати у контактуючі з ним середовища $i$, врешті-решт, надходити в організм людини переважно перорально з харчовими продуктами та питною водою. Метою намого дослідження є гігієнічна оцінка потенційної небезпеки забруднення трунту та міграції в системі «трунт - підземні та поверхневі джерела водопостачання» трьох нових пестищидів з різних хімічних класів у широкому діапазоні трунтово-кліматичних умов. Методи. Об'єктами дослідження були стійкість, екотоксикологічна небезпечність та міграчійна здатність двох гербічидів: амікарбазону з хімічного класу тріазолонових сполук та біииклопірону з класу трикетонів, і фунгіщиду підіфлуметофену з класу карбоксамідів. На основі даних про фізико-хімічні властивості, стабільність у трунті та параметри токсикометрії було проведено оцінку небезпечності досліджуваних речовин в системі «трунт-вода», для чого визначено екотоксикологічну небезпечність (екотокс); оцінено імовірність міграції пестицидів з трунту в підземні води за константою сорбиії органічним вуглецем $\left(K_{\text {od }}\right)$, скринінговим індексом вимивання LIX, індексом потенційного вимивання (GUS) та індексом потенційного забруднення трунтових і річкових вод (LEACH ${ }_{\bmod }$ ).

Результати та обговорення. Встановлено, щьо підіфлуметофен є високостійким (I клас) та мало мобільним (IV клас за $K_{\text {од }}$ у у трунті пестищидом, з широким (від мінімального до майже максимального) потенціалом вилуговування за скринінговим індексом LIX, якому притаманна від дуже низької до високої здатність до вимивання за індексами GUS (від V до II класу) та

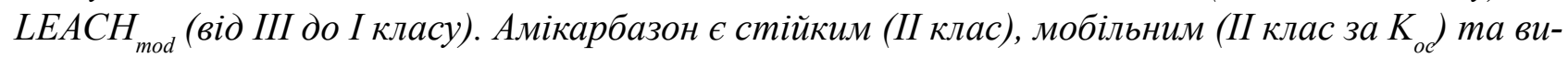
мивним за LIX (практично у будь-яких трунтово-кліматичних умовах) пестицидом з високою (I клас) за LEACH тод та від низької (IV клас) до дуже високої (I клас) за GUS здатністю до вилуговування. Бічиклопірон - високостійкий (I клас) в лабораторних та стійкий (II клас) в польових дослідах; за $K_{\text {ос }} \epsilon$ від дуже мобільного (I клас) до мало мобільного (IV клас), щуо зумовило широкий (від 0 до майже 1) потенщіал вилуговування за LIX, високу (I клас) здатність

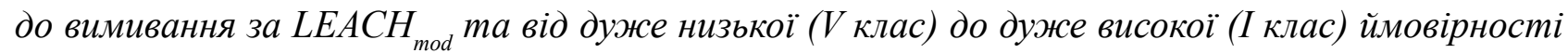
вилуговування за GUS. Екотоксикологічна небезпечність досліджуваних пестицидів за різних трунтово-кліматичних умов є нижчою на 1-5 порядків в порівнянні з ДДТ; до того ж ризик негативного впливу на наземні біоценози бічиклопірону є меншим, ніж амікарбазону та підіфлуметофену. Висновок. Досліджувані речовини є вимивними за скринінговим індексом LIX та показали високу імовірність небезпечного забруднення поверхневих та трунтових вод за індексами GUS та LEACH mод хоча за певних трунтово-кліматичних умов підіфлуметофену та бі-
\end{abstract}

Cite as: Forecasting the degree of pollution in soil, underground and surface water sources by pesticides from the triazolones, triketones and carboxamides classes in a wide range in soil - climatic conditions 
изиклопірону притаманна низька, амікарбазону - помірна здатність до вимивання за індексом GUS. Кінцева очінка ризику для здоров'я людини міграції досліджуваних пестиџидів в системі «трунт-вода» буде надана за результатами досліджень їх поведінки в трунтово-кліматичних умовах Украӥни.

Ключові слова: грунт, міграція, пестициди, підземні води, стабільність.

Вступ. Однією з найбільш актуальних медико-біологічних та еколого-гігієнічних проблем розвитку агропромислового виробництва сьогодення $\epsilon$ застосування різноманітних хімічних засобів захисту рослин (ХЗ3Р) для отримання високих врожаїв сільськогосподарських культур. Наразі світовий ринок пропонує розмаїття асортименту Х3ЗР, зокрема гербіцидів та фунгіцидів, дія яких полягає в знищенні чи пригніченні росту шкідливих рослин (бур'янів) та захисті сільськогосподарських культур від збудників хвороб (фітопатогенів) відповідно. Водночас, поряд з високим економічним ефектом, існує потенційна небезпека широкого застосування пестицидів, зумовлена як їх токсичними властивостями для живих організмів, зокрема ссавців, так і особливостями поведінки у довкіллі. Відомо, що отрутохімікати певних хімічних класів спроможні зберігатися та накопичуватися у грунті протягом тривалого часу, інтенсивно мігрувати у контактуючі з грунтом середовища (атмосферне повітря, товарні частини сільськогосподарських рослин, підземні води та поверхневі водойми) i, врешті-решт, надходити в організм людини, яка не має професійного контакту з ХЗЗР, переважно перорально 3 харчовими продуктами рослинного і тваринного походження (до 70-80 \% від добового надходження) та питною водою (до $10 \%$ від добового надходження).

Напрям розв'язання окресленої проблеми визначено у законі України «Про пестициди та агрохімікати» (№ 86/95-ВР від 02.03.1995), в якому основним принципом державної політики при поводженні $з$ пестицидами визнано пріоритетність збереження здоров'я людини i охорони навколишнього природного середовища по відношенню до економічного ефекту від їх застосування. Законом передбачено, що усі ХЗЗР підлягають обов'язковій державній реєстрації, якій передують державні випро- бування 3 метою біологічної, токсиколого-гігієнічної та екологічної оцінки і розроблення регламентів їх застосування, у тому числі гігієнічних, які мають гарантувати безпечність для здоров'я як сільськогосподарських працівників, так і населення в цілому.

Метою нашого дослідження $\epsilon$ гігієнічна оцінка потенційної небезпеки забруднення грунту та міграції в системі «грунт - підземні та поверхневі джерела водопостачання» трьох нових пестицидів 3 різних хімічних класів у широкому діапазоні грунтово-кліматичних умов.

Методи. Об'єктами дослідження були стійкість, екотоксикологічна небезпечність та міграційна здатність двох гербіцидів: амікарбазону $\left(\mathrm{C}_{10} \mathrm{H}_{19} \mathrm{~N}_{5} \mathrm{O}_{2}\right)$ з хімічного класу тріазолонових сполук та біциклопірону $\left(\mathrm{C}_{19} \mathrm{H}_{2} \mathrm{OF}_{3} \mathrm{NO} 5\right)$ 3 класу трикетонів, і фунгіциду підіфлуметофену $\left(\mathrm{C}_{16} \mathrm{H}_{16} \mathrm{Cl}_{3} \mathrm{~F}_{2} \mathrm{~N}_{3} \mathrm{O}_{2}\right) 3$ класу карбоксамідів. За механізмом дії на шкідливі організми амікарбазон належить до інгібіторів фотосинтезу рослин, біциклопірон - до інгібіторів 4-гідроксифенілпіруват-діоксигенази рослин, підіфлуметофен - до інгібіторів сукцинатдегідрогенази фітопатогенів (Pesticide Properties Data Base [PPDB]).

Вищезазначені діючі речовини входять до складу низки препаратів, які на сьогодні включені у процедуру державної реєстрації в Україні та потребують всебічної гігієнічної оцінки. Серед них - комбіновані препарати Віжн, ВГ та Віжн Про Твін Пак на основі амікарбазону (вміст діючої речовини амікарбазону у препаративній формі 280 г/кг) і монопрепарат Акурон Уно 200 SL, PK на основі біциклопірону (200 г/л), які рекомендовані для захисту посівів кукурудзи від бур'янів. На інших сільськогосподарських культурах зазначені препарати не застосовують у зв'язку з їх фітотоксичністю. На відміну від цього, препарати на основі підіфлуметофену рекомендовані для боротьби 
iз грибковими хворобами широкого спектру культур: овочевих і плодових - монопрепарат Міравіс 200 SC, КC (вміст діючої речовини підіфлуметофену у препаративній формі 200 г/л) і комбінований препарат Міравіс Прайм 400 $\mathrm{SC}, \mathrm{KC}(150$ г/л), зернобобових - комбінований препарат Міравіс Дуо 200 SC, КC (75 г/л), хлібних зернових культур - комбіновані препарати Мipaвic Heo 300 SE, CE (75 г/л) та Міравіс Ейс 275 SE, CE (150 г/л).

Оцінку потенційної небезпеки амікарбазону, біциклопірону та підіфлуметофену здійснювали на підставі даних джерел інформації про їх фізико-хімічні властивості, поведінку у грунті та параметри токсикометрії.

Стабільність досліджуваних речовин у грунті оцінювали за періодом напіврозпаду $\left(\mathrm{DT}_{50}\right)$, який був визначений в лабораторних експериментах в аеробних умовах та в польових (натурних) дослідженнях. Оцінку здійснювали відповідно до чинної в Україні гігієнічної класифікації пестицидів (ДСанПіН 8.8.1.002-98 «Пестициди. Класифікація за ступенем небезпечності», 2000). Згідно з цією класифікацією пестициди за стабільністю у грунті поділяють на чотири класи: I клас - високостійкі $\left(\mathrm{DT}_{50}>60\right.$ діб), II - стійкі (DT ${ }_{50}-31-60$ діб), III- помірно стійкі $\left(\mathrm{DT}_{50}-11-30\right.$ діб) та IV мало стійкі $\left(\mathrm{DT}_{50}<11\right.$ діб) За Міжнародною класифікацію IUPAC пестициди за стабільністю у грунті поділяють на три класи: I класвисокостійкі $\left(\mathrm{DT}_{50}>100\right.$ діб), II- помірно стійкі (30-100 діб), III - мало стійкі (<30 діб) (National Pesticide Information Center [NPIC]).

Оцінку потенційної небезпечності амікарбазону, біциклопірону та підіфлуметофену для наземних екосистем було проведено за методикою Мельникова Н.Н. (1996), яка передбачає визначення екотоксу (Е) з врахуванням норм витрат, персистентності речовини у грунті та основного параметра токсикометріївеличини середньої смертельної дози при пероральному надходженні речовини в організм білих щурів $\left(\mathrm{LD}_{50}\right)$. За одиницю екотокса, прийнято вважати екотоксикологічну небезпечність високостійкого хлорорганічного пестициду дихлордифенілтрихлоретану (ДДТ) при нормі витрат 1 кг/га, персистентності - 312 тижнів і $\mathrm{LD}_{50}-300$ мг/кг. Екотокс дозволяє порівняти екотоксичність досліджуваної речовини та ДДТ і оцінити відносну небезпеку забруднення довкілля цією речовиною.

Величину екотоксу розраховували за формулою (Mel`nikov, N.N., 1996):

$$
E=\frac{P \times N}{L D_{50}}
$$

де $P$ - період напіврозпаду речовини у грунті, тижні; - норма витрати препарату за діючою речовиною, кг/га; $L D_{50}$ - середня смертельна доза за перорального надходження в організм білих щурів, мг/кг.

Оцінку міграційної здатності досліджуваних речовин у системі «грунт-вода» проводили за чотирма показниками: $\mathrm{K}_{\text {ос }}$ (константа сорбції органічним вуглецем), LIX - скринінговий індекс вимивання, GUS (Groundwater Ubiquity Score) - індекс потенційного вимивання, який характеризує ймовірність міграції речовини 3 грунту в підземні води та LEAC$\mathrm{H}_{\bmod }$ - індекс вилуговування для оцінки потенційного забруднення грунтових і річкових вод.

Згідно 3 Міжнародною класифікацію SSLRC (Soil Survey and Land Research Centre), оцінюючи міграційну здатність пестицидів за константою $\mathrm{K}_{\text {ос }}$ виділяють 5 класів: I - дуже мобільні $\left(\mathrm{K}_{\text {ос }}<15\right.$ мл/Г), ІІ - мобільні (1574 мл/г), ІІІ - помірно мобільні (75-499 мл/г), IV - мало мобільні (500-4000 мл/г), V - не мобільні (> 4000 мл/г) (Agricultural Substances Databases Agriculture \& Environment Research Unit).

Розрахунок скринінгового індексу вимивання LIX проводили за формулою (Claudia A.S., 2002):

$$
\mathrm{LIX}=\exp \left(-k \cdot K_{o c}\right),
$$

де $k$ - константа швидкості руйнації речовини за рівнянням першого порядку, доба ${ }^{-1}, K_{o c}-$ коефіцієнт сорбції органічним вуглецем, мл/г.

Індекс LIX варіюється від 0 (мінімальний потенціал вилуговування) до 1 (максимальний потенціал вилуговування) і дозволяє виявити невимивні (LIX $=0$ ) та вимивні (LIX $\geq 0,1)$ пестициди, тоді як діапазон від 0 до 0,1 характеризується як зона переходу (Claudia A.S., 2002).

Індекс потенційного вимивання розраховували за формулою (Gustafson D.I., 1989): 


$$
\mathrm{GUS}=\lg \mathrm{DT}_{50} \times\left(4-\lg \mathrm{K}_{\mathrm{oc}}\right),
$$

де GUS - індекс потенційного вимивання, у.о.; $\mathrm{DT}_{50}$ - період напіврозпаду речовини у грунті, доба; $\mathrm{K}_{\text {ос }}$ - константа сорбції органічним вуглецем, мл/г.

Потенціал вимивання пестициду у грунтові води є високим, якщо величина GUS > 2,8; помірним - якщо GUS у межах $1,8-2,8$; низьким - якщо GUS у межах 0-1,8; дуже низькимякщо GUS < 0 (Groundwater Ubiquity Score [GUS]). Також існує більш деталізована шкала оцінки, за якою можливість вимивання вважається дуже високою (I клас), якщо GUS > 4,0; високою (II) - якщо GUS у межах 3,0-4,0; помірною (III) - у межах 2,0-3,0; низькою (IV) у межах 1,0-2,0; дуже низькою (V) - у межах 0,1-1,0 та надзвичайно низькою (VI) - якщо GUS $<0,1$ - (Vogue, Kerle \& Jenkins, 1994).

Для оцінки потенційного забруднення грунтових і річкових вод використовували формулу (Рapa E. et al, 2004):

$$
L E A C H_{\text {mod }}=\underline{S}_{w} \times \frac{D T_{1}}{K_{o c}} \text { field , }
$$

де $L E A C H_{\text {mod }}$ - індекс вилуговування, бали; $S_{w}-$ розчинність речовини у воді, мг/л; $D T_{50 \text { field }}-$ період напівруйнування речовини у грунті в натурних умовах, доба; $K_{\text {ос }}$ - константа сорбції органічним вуглецем, мл/г.

Згідно з класифікацією за $\mathrm{LEACH}_{\text {mod }}$ пестициди розділяють на 3 класи: I клас - високий ризик забруднення поверхневих та підземних вод $\left(\mathrm{LEACH}_{\bmod }>2,0\right)$, II клас - помірний ризик $\left(\mathrm{LEACH}_{\text {mod }} 1,1-2,0\right)$, III клас - низький $\left(\mathrm{LEACH}_{\text {mod }}<1,0\right)$.

Результати та обговорення. Потенційна небезпечність хімічних засобів захисту рослин для здоров'я населення та навколишнього середовища пов'язана не лише з їх токсичними властивостями, а й з їх поведінкою у довкіллі, а саме зі стійкістю та міграційною здатністю. Міграція пестицидів 3 грунту у водні об'єкти та накопичення їх залишків у грунті та в підземних водах залежать як від грунтово-кліматичних умов (механічний склад, $\mathrm{pH}$, вміст гумусу у грунті, його температура та вологість, інсоляція), так і від хімічної будови та фізико-хімічних властивостей речовини. Зокрема, на персистентність пестицидів у грунті впли- ває адсорбція їх грунтовими колоїдами, гідролітична стійкість, фотолітична деградація, мікробіологічна деструкція тощо (Goncharuk, E.I., 1986).

Амікарбазон за стабільністю у грунті в лабораторних (аеробних) умовах можна віднести як до помірно стійких (III клас небезпечності), так і до високостійких (І клас) пестицидів відповідно до (Пестициди. Класифікація за ступенем небезпечності: ДСанПіН 8.8.1.00298, 2000), оскільки період напіврозпаду у різних типах грунтів коливався у широкому діапазоні - 14-87 днів (табл. 1). В польових дослідженнях амікарбазон деградував з періодом напіврозпаду 18-87 днів (Public Release Summary (PRS), 2018; US EPA-Pesticides, 2005; PPDB), а на ділянках цукрового очерету в Австралії - навіть 4-18 днів (Public Release Summary (PRS), 2018), що дозволяє віднести амікарбазон як до високо стійких (I клас), так і до мало стійких (IV клас) пестицидів за ДСанПіН 8.8.1.002-98 «Пестициди. Класифікація за ступенем небезпечності». Основним шляхом руйнації речовини у грунті визнають біодеградацію. Очікують, що деградація амікарбазону відбуватиметься швидше в лужних грунтах через можливий додатковий внесок гідролізу, тоді як фотоліз не вважають важливим шляхом деградації у грунті (Public Release Summary (PRS), 2018).

Стабільність біциклопірону досліджено у різних типах грунтів: суглинку, піщано-глинистому суглинку, глинистому суглинку, мулистому суглинку, мулистому глинистому суглинку, мулистій глині, суглинистому піску (Malhat F.M., 2017). Період напіврозпаду ( $\mathrm{DT}_{50}$ ) сполуки коливався у широкому діапазоні залежно від механічного складу грунту, його $\mathrm{pH}$, вмісту органічної речовини: в лабораторних дослідах - 19,8-434 днів, в польових - 1,7-36 днів (табл. 1). Згідно з ДСанПіН 8.8.1.002-98 за стабільністю у грунті біциклопірон можна віднести в лабораторних умовах як до помірно стійких (III клас), так і до високостійких (I клас) пестицидів; в натурних-як до малостійких (IV клас), так і до стійких (II клас) пестицидів. За міжнародною класифікацією IUPAC біциклопірон також класифікується від мало стійкого (III клас) до високостійкого (I клас) 
Таблиця 1. Оцінка стабільності у грунті амікарбазону, біциклопірону та підіфлуметофену

\begin{tabular}{|c|c|c|c|c|c|c|c|c|c|}
\hline \multirow{3}{*}{ Діюча речовина } & \multirow{3}{*}{$\begin{array}{c}\text { Джерело } \\
\text { інформації щодо } \\
\text { значень DT } \\
50\end{array}$} & \multicolumn{4}{|c|}{$\mathrm{DT}_{50}$, доба } & \multicolumn{4}{|c|}{ Клас* } \\
\hline & & \multicolumn{2}{|c|}{$\begin{array}{l}\text { лабораторні } \\
\text { умови (ЛУ) }\end{array}$} & \multicolumn{2}{|c|}{$\begin{array}{c}\text { польові умови } \\
\text { (ПУ) }\end{array}$} & \multicolumn{2}{|c|}{$\begin{array}{c}\text { за ДСанПін } \\
\text { 8.8.1002-98 }\end{array}$} & \multicolumn{2}{|c|}{ за IUPAC } \\
\hline & & $\min$ & $\max$ & $\min$ & $\max$ & ЛУ & Пу & ЛУ & Пу \\
\hline \multirow{3}{*}{ Амікарбазон } & \begin{tabular}{|l|} 
Public Release \\
Summary, 2018 \\
\end{tabular} & 14 & 87 & 4 & 30 & $\mathrm{III} / \mathrm{I}$ & IV / III & III / II & III / II \\
\hline & \begin{tabular}{|l|} 
US EPA- \\
Pesticides, 2005
\end{tabular} & - & 87 & 19 & 29 & $-/ \mathrm{I}$ & III / III & $-/ \mathrm{II}$ & III / III \\
\hline & PPDB & 15 & 87 & 18 & 87 & III / I & III / I & III / II & III / II \\
\hline \multirow{2}{*}{ Біциклопірон } & \begin{tabular}{|l|} 
Public Release \\
Summary, 2017 \\
\end{tabular} & 19,8 & 434 & 1,7 & 36 & $\mathrm{III} / \mathrm{I}$ & IV / II & III / I & III / II \\
\hline & Malhat F.M., 2017 & 19,8 & 433 & - & - & $\mathrm{III} / \mathrm{I}$ & - & $\mathrm{III} / \mathrm{I}$ & - \\
\hline \multirow{3}{*}{ Підіфлуметофен } & \begin{tabular}{|l|} 
Public Release \\
Summary, 2018 \\
\end{tabular} & 398 & 1690 & - & - & $\mathrm{I} / \mathrm{I}$ & - & $\mathrm{I} / \mathrm{I}$ & - \\
\hline & PPDB & 469 & $\begin{array}{c}4170 \\
1440 * * \\
\end{array}$ & 29 & 8540 & $\begin{array}{l}\mathrm{I} / \mathrm{I} \\
\mathrm{I} * * \\
\end{array}$ & III / I & $\begin{array}{ll}\mathrm{I} / \mathrm{I} \\
\mathrm{I} * * \\
\end{array}$ & III / I \\
\hline & \begin{tabular}{|l|} 
Department of \\
agriculture, 2018
\end{tabular} & 84 & 811 & - & - & $\mathrm{I} / \mathrm{I}$ & - & $\mathrm{I} / \mathrm{I}$ & - \\
\hline
\end{tabular}

Примітки:

1. * - клас за мінімальним значенням / клас за максимальним значенням;

2. ** - середнє значення.

в лабораторних та помірно стійкого (II клас) в натурних умовах (табл. 1).

Період напіврозпаду підіфлуметофену у різних типах грунтів коливався у широкому діапазоні як в лабораторних (84-4170 днів), так і в польових (29-8540 днів) умовах (табл. 1). В більшості випадків за стабільністю у грунті цю речовину можна віднести до I класу небезпечності (високостійкий) і лише в окремих натурних дослідженнях - до II (стійкий, або III (помірно стійкий) класів небезпечності за ДСанПіН 8.8.1.002-98.

Таким чином, узагальнюючи інформацію 3 урахуванням принципу агравації - одного 3 основних принципів профілактичної медицини, амікарбазон за стабільністю у грунті як в лабораторних, так і в польових умовах можна віднести за ДСанПіН 8.8.1.002-98 до високо стійких (I клас небезпечності) пестицидів, за міжнародною класифікацію IUPAC - до помірно стійких (II клас) пестицидів; біциклопірон - до високостійких (I клас за обома класифікаціями) в лабораторних експериментах та до помірно стійких (II клас за міжнародною класифікацію IUPAC) - в польових дослідах; підіфлуметофен - до високостійких пестицидів як в лабораторних, так і в натурних умовах (I клас за обома класифікаціями). Найвищу стабільність у різних грунтово-кліматичних умовах має підіфлуметофен; наступним є біциклопірон; найшвидше деградує у грунті амікарбазон.

Для оцінки відносної екотоксикологічної небезпечності було розраховано екотокс досліджуваних пестицидів за методикою Мельникова Н.Н. (1996). Встановлено, що ризик негативного впливу усіх досліджуваних речовин на наземні біоценози за різних грунтово-кліматичних умов $\epsilon$ нижчим на 1-5 порядків в порівнянні з ДДТ; до того ж екотоксичність біциклопірону є нижчою, ніж амікарбазону та підіфлуметофену (табл. 2).

У порівнянні з екотоксикологічною небезпечністю інших гербіцидів екотокс біциклопірону $\left(1,54 \times 10^{-4}\right)$, розрахований з урахуванням найвищої стійкості у польових дослідженнях, був нижчим, ніж екотокс сим-триазинів та шестичленних гетероциклів, співставним 
3 екотоксом імідазолінонів та вищим, ніж у оксазолів, сульфонілсечовин та деяких інших гербіцидів (табл. 3). Екотоксичність амікарбазону $\left(1,71 \times 10^{-3}\right)$ була нижчою, ніж сим-триазинів та деяких шестичленних гетероциклів, але вищою, ніж у імідазолінонів, оксазолів, сульфонілсечовин та гербіцидів 3 інших хімічних класів (табл. 3). Щодо фунгіциду підіфлуметофену, його екотоксикологічна небезпечність $\left(8,78 \times 10^{-2}\right)$, визначена з урахуванням найвищої стійкості у польових дослідженнях, була вищою у порівнянні з іншими фунгіцидами: етилен-біс-дитіокарбаматами, стробілуринами та амідами (табл. 3).

Оскільки стійкі екзогенні хімічні речовини (EXP) спроможні накопичуватися та створювати депо у грунті, а грунт, водночас, є провідною ланкою міграції ЕXР, у тому числі й досліджуваних сполук, у біосфері, нами було проведено оцінку ймовірності забруднення підземних вод та поверхневих водойм в різних грунтово-кліматичних умовах.

Оцінку ризику такої міграції проводили за коефіцієнтом сорбції органічним вуглецем грунту $\left(\mathrm{K}_{\text {ос }}\right)$ та на підставі визначення трьох індексів: 1) скринінгового індексу вимивання LIX, виходячи 3 константи швидкості руйнації речовини у грунті за рівнянням першого порядку $\mathrm{k}$ та коефіцієнту сорбції органічним вуглецем (Claudia A.S., 2002); 2) індексу по- тенційного вимивання GUS, базуючись на показниках $\mathrm{DT}_{50}$ у грунті та $\mathrm{K}_{\mathrm{oc}}$ (Gustafson, 1989) та 3 ) індексу вилуговування LEACH ${ }_{\text {mod, }}$ спираючись на розчинність речовини у воді, DT 50 грунті в натурних умовах та $\mathrm{K}_{\text {ос }}$ (Papa E. et al, 2004).

Встановлено, що амікарбазон в лабораторних дослідженнях дуже рухливий у грунті. Оскільки амікарбазон не дисоціює, то очікують, що рН грунту навряд чи вплине на його рухливість (Public Release Summary, 2018).

Біциклопірон також має дуже високу рухливість у більшості грунтів (17 з 23 випробуваних); найнижче значення $\mathrm{K}_{\text {ос }}$ становить 6 мл/Г (табл. 4). В трьох інших грунтах було виявлено високу рухливість ( $\mathrm{K}_{\text {ос }}$ в межах 50-150 мл/г), а ще у трьох грунтах - середню рухливість $\left(\mathrm{K}_{\text {ос }}\right.$ в межах 150-500 мл/г). Не виявлено кореляційного зв'язку $(r=0,11)$ між вмістом органічного вуглецю у грунті та адсорбцією біциклопірону (Public release summary on the evaluation of the new active bicyclopyrone, 2017).

Коефіцієнт адсорбції підіфлуметофену визначено у 6 різних грунтах. Значення $\mathrm{K}_{\text {ос }}$ коливались від 1165 до 2206 мл/г (середнє геометричне значення - 1706 мл/г) та не були пов'язані з рН грунту. Речовину класифікували як таку, що має низьку або незначну потенційну рухливість у грунті (European Commission. Pydiflumetofen. 2019).

Таблиця 2. Оцінка екотоксикологїчної небезпечність амікарбазону, біциклопірону та підіфлуметофену

\begin{tabular}{|c|c|c|c|c|c|c|}
\hline \multirow[b]{2}{*}{$\begin{array}{c}\text { Діюча } \\
\text { речовина }\end{array}$} & \multicolumn{2}{|c|}{ DT50 (min - max), доба } & \multirow{2}{*}{$\begin{array}{c}\text { Норма } \\
\text { витрати } \\
\text { діючої } \\
\text { речовини } \\
(\mathbf{N}), \text { кг } / \text { га } \\
\end{array}$} & \multirow{2}{*}{$\begin{array}{c}\text { Середня } \\
\text { смертельна } \\
\text { доза } \\
\text { (LD50), } \\
\text { мг/кг } \\
\end{array}$} & \multicolumn{2}{|c|}{ Екотокс $(\mathbf{E}) *$, у.о. } \\
\hline & $\begin{array}{c}\text { Лабораторні } \\
\text { умови }\end{array}$ & $\begin{array}{c}\text { Польові } \\
\text { умови }\end{array}$ & & & $\begin{array}{c}\text { Лабораторні } \\
\text { умови }\end{array}$ & $\begin{array}{c}\text { Польові } \\
\text { умови }\end{array}$ \\
\hline Амікарбазон & $14-87$ & $4-87$ & 0,14 & 1015 & $\begin{array}{l}2,76 \times 10-4 \\
1,71 \times 10-3\end{array}$ & $\begin{array}{l}7,88 \times 10-5 \\
1,71 \times 10-3 \\
\end{array}$ \\
\hline Біциклопірон & $19,8-434$ & $1,7-36$ & 0,15 & 5000 & $\begin{array}{l}8,48 \times 10-5 \\
1,86 \times 10-3\end{array}$ & $\begin{array}{l}7,28 \times 10-6 \\
1,54 \times 10-4\end{array}$ \\
\hline Підіфлуметофен & $84-4170$ & $\begin{array}{l}29- \\
8540\end{array}$ & $0,36^{* *}$ & 5000 & $\begin{array}{l}8,64 \times 10-4 \\
4,29 \times 10-2\end{array}$ & $\begin{array}{l}2,95 \times 10-4 \\
8,78 \times 10-2\end{array}$ \\
\hline
\end{tabular}

Примітки:

1. * - в чисельнику - мінімальне значення, в знаменнику - максимальне значення;

2. ** - норма витрати підіфлуметофену визначена з врахуванням регламентованої кратності обробокдворазово за вегетаційний сезон. 
Таблиця 3. Порівняльна оцінка екотоксикологічної небезпечності гербіцидів та фунгіцидів різних хімічних класів та поколінь

\begin{tabular}{|c|c|c|c|c|}
\hline Пестициди & Хімічний клас & Речовина & Екотокс & $\begin{array}{c}\text { Джерело } \\
\text { Інформації }\end{array}$ \\
\hline \multirow{19}{*}{ Гербіциди } & \multirow{3}{*}{ Сим-триазини } & Атразин & $3,09 \times 10-2$ & \multirow{6}{*}{$\begin{array}{l}\text { Mel'nikov, N.N., } \\
1997\end{array}$} \\
\hline & & Пропазин & $1,17 \times 10-2$ & \\
\hline & & Симазин & $7,45 \times 10-2$ & \\
\hline & \multirow{3}{*}{$\begin{array}{l}\text { Шестичленні } \\
\text { гетероцикли }\end{array}$} & Бентазон & $1,02 \times 10-2$ & \\
\hline & & Метрибузин & $3,00 \times 10-3$ & \\
\hline & & Хлоридазон & $4,20 \times 10-4$ & \\
\hline & \multirow{3}{*}{ Імідазолінони } & Імазетапір & $2,07 \times 10-4$ & \multirow{3}{*}{$\begin{array}{l}\text { Gorbachevs'kij, } \\
\text { R.V., \& Korshun, } \\
\text { M.M., } 2012\end{array}$} \\
\hline & & Імазапір & $1,13 \times 10-4$ & \\
\hline & & Імазамокс & $2,24 \times 10-5$ & \\
\hline & $\begin{array}{l}\text { Сульфоніламіно- } \\
\text { карбонілтриазолінони }\end{array}$ & Тієнкарбазон-метил & $5,40 \times 10-5$ & \multirow{4}{*}{$\begin{array}{l}\text { Antonenko, } \\
\text { A.M., } 2014\end{array}$} \\
\hline & Бензоїлпіразоли & Топрамезон & $8,25 \times 10-5$ & \\
\hline & Трикетони & Мезотріон & $3,90 \times 10-5$ & \\
\hline & Оксазоли & Ізоксафлютол & $2,48 \times 10-5$ & \\
\hline & \multirow{6}{*}{ Сульфонілсечовини } & Просульфурон & $3,04 \times 10-5$ & \multirow{5}{*}{$\begin{array}{l}\text { Karpenko, V.V., } \\
2009\end{array}$} \\
\hline & & Тритосульфурон & $1,60 \times 10-5$ & \\
\hline & & Трибенурон-метил & $3,76 \times 10-6$ & \\
\hline & & Метсульфурон-метил & $2,51 \times 10-6$ & \\
\hline & & Тріасульфурон & $1,24 \times 10-6$ & \\
\hline & & $\begin{array}{l}\text { Йодсульфурон-метил } \\
\text { натрію }\end{array}$ & $1,20 \times 10-6$ & $\begin{array}{l}\text { Antonenko, } \\
\text { A.M., } 2014\end{array}$ \\
\hline \multirow{6}{*}{ Фунгіциди } & \multirow[b]{2}{*}{$\begin{array}{l}\text { Етилен-біс- } \\
\text { дитіокарбамати }\end{array}$} & Метирам & $9,5 \times 10-4$ & \multirow{2}{*}{$\begin{array}{l}\text { Vavrinevich, } \\
\text { O.P., Omel'chuk, } \\
\text { S.T., \& Bardov, } \\
\text { V.G., } 2014\end{array}$} \\
\hline & & Манкоцеб & $7,00 \times 10-4$ & \\
\hline & \multirow{2}{*}{ Стробілурини } & Крезоксим-метил & $1,60 \times 10-4$ & \multirow{2}{*}{$\begin{array}{l}\text { Korshun, O.M., } \\
2008\end{array}$} \\
\hline & & Трифлоксистробін & $1,20 \times 10-4$ & \\
\hline & \multirow{2}{*}{ Аміди } & Флуксапіроксад & $1,39 \times 10-4$ & \multirow{2}{*}{$\begin{array}{l}\text { Antonenko, } \\
\text { A.M., } 2014\end{array}$} \\
\hline & & Цифлуфенамід & $1,18 \times 10-5$ & \\
\hline
\end{tabular}

Узагальнені дані різних джерел інформації щодо значень коефіцієнту сорбції органічним вуглецем грунту $\left(\mathrm{K}_{\text {ос }}\right)$ досліджуваних речовин (табл. 4) дозволили віднести амікарбазон до II класу, мобільний; підіфлуметофен - до IV класу, мало мобільний; біциклопірон - залежно від типу грунту від дуже мобільний (I клас) до мало мобільний (IV клас) в окремих грунтах згідно з Міжнародною класифікацією SSLRC (Agricultural Substances Databases Agriculture \& Environment Research Unit).

За скринінговим індексом вимивання LIX (табл. 4) амікарбазон можна класифікувати як вимивний пестицид практично у будь-яких грунтово-кліматичних умовах, тоді як індекс LIX біциклопірону та підіфлуметофену варіює від 0 (мінімальний потенціал вилуговування, невимивний пестицид) до майже 1 (максимальний потенціал вилуговування) як в лабораторних, так і в польових дослідженнях.

Здатність до вимивання за індексом GUS амікарбазону $(1,42-5,39$ у.о.) оцінена від низької (IV клас) до дуже високої (I клас); біциклопірону $(0,30$ - 8,50 у.о. $)$ - від дуже низької (V клас) до дуже високої (I клас); підіфлуме- 
Таблиця 4. Оцінка мобільності амікарбазону, біциклопірону та підіфлуметофену за коефіцієнтом сорбції органічним вуглецем грунту та індексом LIX

\begin{tabular}{|c|c|c|c|c|c|c|c|c|}
\hline \multirow[b]{2}{*}{$\begin{array}{c}\text { Діюча } \\
\text { речовина }\end{array}$} & \multicolumn{2}{|c|}{$\begin{array}{c}\mathbf{k}^{*}(\min -\max ) \\
\text { доба-1 }\end{array}$} & \multirow{2}{*}{$\begin{array}{c}\text { Джерело } \\
\text { інформації } \\
\text { щодо значень } \\
\text { Кос }\end{array}$} & \multicolumn{2}{|c|}{ Кос, мл/г } & \multirow{2}{*}{$\begin{array}{c}\text { Клас } \\
\text { за } \\
\text { SSLRC }\end{array}$} & \multicolumn{2}{|c|}{ LIX } \\
\hline & $\begin{array}{c}\text { Лабора- } \\
\text { торні } \\
\text { умови }\end{array}$ & $\begin{array}{c}\text { Польові } \\
\text { умови }\end{array}$ & & $\min$ & Max & & $\begin{array}{c}\text { Лабора- } \\
\text { торні } \\
\text { умови }\end{array}$ & $\begin{array}{c}\text { Польові } \\
\text { умови }\end{array}$ \\
\hline \multirow{2}{*}{ Амікарбазон } & \multirow{2}{*}{$\begin{array}{c}0,00793 \\
- \\
0,04928\end{array}$} & \multirow{2}{*}{$\begin{array}{c}0,00793 \\
- \\
0,1725\end{array}$} & $\begin{array}{c}\text { US EPA- } \\
\text { Pesticides, } 2005\end{array}$ & 16,7 & 37 & II & \multirow{2}{*}{$\begin{array}{l}0,1144 \\
0,8760\end{array}$} & \multirow{2}{*}{$\begin{array}{l}0,0005 \\
0,8760\end{array}$} \\
\hline & & & PPDB & 23 & 44 & II & & \\
\hline Біциклопірон & $\begin{array}{c}0,00159 \\
- \\
0,03485\end{array}$ & $\begin{array}{c}0,01917 \\
- \\
0,40588\end{array}$ & $\begin{array}{l}\text { Public Release } \\
\text { Summary, } 2017\end{array}$ & 6 & 500 & I - IV & $\begin{array}{l}0,0000 \\
0,9905\end{array}$ & $\begin{array}{l}0,0000 \\
0,8914\end{array}$ \\
\hline \multirow{3}{*}{ Підіфлуметофен } & \multirow{3}{*}{$\begin{array}{c}0,00017 \\
- \\
0,00821\end{array}$} & \multirow{3}{*}{$\begin{array}{c}0,00008 \\
- \\
0,02379\end{array}$} & $\begin{array}{l}\text { Public Release } \\
\text { Summary, } 2018 \\
\end{array}$ & 1949 & 3808 & IV & \multirow{3}{*}{$\begin{array}{l}0,0000 \\
0,8247\end{array}$} & \multirow{3}{*}{$\begin{array}{l}0,0000 \\
0,9102\end{array}$} \\
\hline & & & $\begin{array}{l}\text { Public Release } \\
\text { Summary, 2018; } \\
\text { PPDB }\end{array}$ & 1165 & 2206 & IV & & \\
\hline & & & $\begin{array}{l}\text { Department } \\
\text { of agriculture, } \\
2018\end{array}$ & 1383 & 2463 & IV & & \\
\hline
\end{tabular}

Примітка. * - значення константи швидкості руйнації речовини за рівнянням першого порядку $\mathrm{k}$ розраховано за формулою: (Claudia A.S., 2002); значення DT 50 взято з табл. 2.

тофену (0,61-3,65 у.о.) - від дуже низької (V клас) до високої (ІІ клас) (табл. 5).

Крім того нами визначено ризик потенційного забруднення поверхневих та підземних вод за індексом $\mathrm{LEACH}_{\text {mod }}$, що враховує не лише $\mathrm{DT}_{50}$ та $\mathbf{K}_{\text {ос }}$ речовини, але й ії розчин- ність у воді $\left(\mathrm{S}_{\mathrm{w}}\right)$ відповідно до методики (Рара E. et al, 2004). Встановлено (табл. 5), що ризик забруднення поверхневих та грунтових вод амікарбазоном $(418,18-9095,45)$ та біциклопіроном (404,6-714000) є високим (I клас); підіфлуметофеном $(0,020-10,996)$ - як високим

Таблиця 5. Оцінка міграційної здатності амікарбазону, біциклопірону та підіфлуметофену в системі «грунт-вода»

\begin{tabular}{|c|c|c|c|c|c|c|c|c|c|}
\hline \multirow{3}{*}{$\begin{array}{c}\text { Діюча } \\
\text { речовина }\end{array}$} & \multicolumn{2}{|c|}{$\begin{array}{c}\text { DT50 (min - } \\
\text { max), доба }\end{array}$} & \multirow{3}{*}{$\begin{array}{c}\text { Koc } \\
(\min - \\
\max ), \\
\text { Мл/Г }\end{array}$} & \multicolumn{4}{|c|}{ GUS } & \multicolumn{2}{|c|}{ LEACH $_{\text {mod }} * *$} \\
\hline & \multirow{2}{*}{ ЛУ } & \multirow{2}{*}{ ПУ } & & \multicolumn{2}{|c|}{ Значення, у.о* } & \multicolumn{2}{|c|}{ Клас } & \multirow{2}{*}{$\begin{array}{c}\text { Значення, } \\
\text { бали* }\end{array}$} & \multirow{2}{*}{ Клас } \\
\hline & & & & ЛУ & ПУ & ЛУ & ПУ & & \\
\hline Амікарбазон & $14-87$ & $4-87$ & $16,7-44$ & $\begin{array}{l}2,70 \\
5,39\end{array}$ & $\begin{array}{l}1,42 \\
5,39\end{array}$ & I - III & I - IV & $\begin{array}{c}418,18 \\
9095,45\end{array}$ & I \\
\hline Біциклопірон & $\begin{array}{c}19,8- \\
434 \\
\end{array}$ & $1,7-36$ & $6-500$ & $\begin{array}{l}1,69 \\
8,50 \\
\end{array}$ & $\begin{array}{l}0,30 \\
5,01 \\
\end{array}$ & $\mathrm{I}-\mathrm{IV}$ & $\mathrm{I}-\mathrm{V}$ & $\begin{array}{c}404,6 \\
714000\end{array}$ & I \\
\hline Підіфлуметофен & $\begin{array}{l}84- \\
4170\end{array}$ & $\begin{array}{l}29- \\
8540\end{array}$ & $\begin{array}{c}1165- \\
3808\end{array}$ & $\begin{array}{l}0,80 \\
3,38\end{array}$ & $\begin{array}{l}0,61 \\
3,67\end{array}$ & $\mathrm{II}-\mathrm{V}$ & $\mathrm{II}-\mathrm{V}$ & $\begin{array}{l}0,02 \\
11,0\end{array}$ & $\begin{array}{l}\text { I- } \\
\text { III }\end{array}$ \\
\hline
\end{tabular}

Примітки:

1. ЛУ - лабораторні умови, ПУ - польові умови;

2. * - в чисельнику - мінімальне значення, в знаменнику - максимальне значення;

3. ** - при визначенні $\mathrm{LEACH}_{\mathrm{mod}}$ враховано розчинність у воді $\left(\mathrm{S}_{\mathrm{w}}\right)$ : амікарбазону -4600 мг/л, біциклопірону - 119000 мг/л, підіфлуметофену - 1,5 мг/л. 
(I клас), так і низьким (III клас) залежно від грунтово-кліматичних умов.

Таким чином, підіфлуметофен $є$ високостійким (I клас) та мало мобільним (IV клас за $\mathrm{K}_{\text {ос }}$ ) у грунті пестицидом, з широким (від мінімального до майже максимального) потенціалом вилуговування за скринінговим індексом LIX, якому притаманна від дуже низької до високої здатність до вимивання за індексами GUS (від V до II класу) та $\mathrm{LEACH}_{\text {mod }}$ (від III до I класу). Амікарбазон є стійким (II клас), мобільним (II клас за $\mathrm{K}_{\text {ос }}$ ) та вимивним за LIX (практично у будь-яких грунтово-кліматичних умовах) пестицидом з високою за $\mathrm{LEACH}_{\text {mod }}$ (I клас) та від низької (IV клас) до дуже високої (I клас) за GUS здатністю до вилуговування. Біциклопірон - високостійкий (I клас) в лабораторних та стійкий (II клас) в польових дослідах; за $\mathrm{K}_{\text {ос }} є$ від дуже мобільного (І клас) до мало мобільного (IV клас), що зумовило широкий (від 0 до майже 1) потенціал вилуговування за LIX, високу (I клас) здатність до вимивання за $\mathrm{LEACH}_{\text {mod }}$ та від дуже низької (V клас) до дуже високої (I клас) ймовірності вилуговування за GUS.

\section{Висновки:}

1. Амікарбазон за стабільністю у грунті $\epsilon$ стійким як в лабораторних (аеробних) умовах, так і в натурних дослідженнях; біциклопірон - високостійким в лабораторних експериментах та помірно стійким - в польових дослідах; підіфлуметофен високостійким як в лабораторних, так і в натурних умовах. Найвищу стабільність у різних грунтово-кліматичних умовах має підіфлуметофен; наступним є біциклопірон; амікарбазон деградує у грунті найшвидше.

2. Екотоксикологічна небезпечність досліджуваних пестицидів за різних грунтово-кліматичних умов $\epsilon$ нижчою на 1-5 порядків в порівнянні 3 високостійким хлорорганічним пестицидом дихлордифенілтрихлоретаном (ДДТ); до того ж ризик негативного впливу біциклопірону на наземні біоценози є меншим, ніж амікарбазону та підіфлуметофену. Екотоксичність гербіцидів біциклопірону та амікарбазону, визначена 3 у рахуванням найвищої стійкості у польових дослідженнях, була нижчою, ніж екотоксичність сим-триазинів та шестичленних гетероциклів, співставною 3 екотоксом імідазолінонових гербіцидів (біциклопірон) та вищою, ніж у оксазолів, сульфонілсечовин та гербіцидів 3 інших хімічних класів. Екотоксикологічна небезпечність фунгіциду підіфлуметофену була вищою у порівнянні з іншими фунгіцидами: етилен-біс-дитіокарбаматами, стробілуринами та амідами.

3. Досліджувані речовини (амікарбазон, біциклопірон та підіфлуметофен) є вимивними за скринінговим індексом LIX та показали високу імовірність небезпечного забруднення поверхневих та підземних вод за індексами GUS та $\mathrm{LEACH}_{\bmod }$ (I клас), яка зумовлена високою стабільністю у грунті підіфлуметофену, низькою сорбційною здатністю амікарбазону та високою стабільністю і низькою сорбційною здатністю біциклопірону. В той же час за певних грунтово-кліматичних умов біциклопірон та підіфлуметофен $\epsilon$ майже невимивними пестицидами за скринінговим індексом LIX; підіфлуметофену притаманна дуже низька здатність до вимивання за індексами GUS (V клас) та $\mathrm{LEACH}_{\text {mod }}$ (III клас), амікарбазону - низька (IV клас) та біциклопірону дуже низька (V клас) здатність до вимивання за індексом GUS.

4. Кінцева оцінка ризику для здоров'я людини міграції досліджуваних пестицидів 3 грунту у підземні та поверхневі водойми та екотоксикологічного ризику для наземних біоценозів при застосуванні у сільському господарстві препаратів на основі амікарбазону, біциклопірону та підіфлуметофену буде надана після досліджень їх поведінки в системі «грунт - суміжні середовища» в грунтово-кліматичних умовах України.

Конфлікт інтересів. Не має ніякого конфлікту інтересів, який міг би завдати шкоди неупередженості дослідження.

Фінансування. Дана стаття не отримала фінансової підтримки від державної, громадської або комерційної організації. 


\section{ЛІТЕРАТУРА}

Agricultural Substances Databases Agriculture \& Environment Research Unit. University of Hertfordshire. http:// sitem.herts.ac.uk/aeru/iupac/docs/Background_and_Support.pdf

Antonenko, A.M. (2014). Oczinka ekotoksikologichnoï nebezpechnosti ta riziku zabrudnennya pidzemnix vod novimi pesticidami ingibitorami 4-gidroksifenilpiruvatdioksigenazi ta ingibitorami mikrosomal'nix fermentiv. Aktual'ni problemi suchasnoï medicini, 14(3), 43-47.

Claudia A.S. (2002). Screening method for assessing pesticide leaching potential. Pesticidas: R. Ecotoxicol. Curitiba. (12), 69-78. https://doi.org/10.5380/pes.v12i0.3151

Department of agriculture. Pydiflumentonfen. New Active Ingredient Review. CAS 1228284-64-7; EPA PC CODE 090110 (2018), 1-2. https://www.mda.state.mn.us/sites/default/files/inline-files/Pydiflumetofen.pdf

European Commission. Pydiflumetofen. Volume 1 (2019), 280. https://echa.europa.eu/documents/10162/da5eb3c80089-60e5-44e5-68936d4f26e6

Gorbachevs'kij , R.V., \& Korshun , M.M. (2012). Gigienichna oczinka ekotoksikologichnix rizikiv zastosuvannya imidazolinonovix gerbicidiv. Zbirnik naukovix pracz`spivrobitnikiv NMAPO imeni P.L. Shupika, 373-377.

Goncharuk, E.I., \& Sidorenko, G.I. (1986). Gigienicheskoe normirovanie ximicheskix veshhestv v pochve: Rukovodstvo. M.: Medicina.

Groundwater Ubiquity Score (GUS). National pesticide information center. http://npic.orst.edu/envir/gus.html

Gustafson D.I. (1989). Groundwater ubiquity score: a simple method for assessing pesticide leachability. Environmental Toxicology and Chemistry. (8), 339-357. https://doi.org/10.1002/etc.5620080411

Karpenko, V.V. (2009). Hihiienichna otsinka herbitsydiv - pokhidnykh sulfonilsechovyny ta naukove obgruntuvanniam rehlamentiv yikh bezpechnoho zastosuvannia na zernovykh kulturakh. (Masterss thesis). Natsionalnyi medychnyi universytet im. O.O. Bohomoltsia, Kyiv.

Korshun, O.M. (2008). Ekoloho-hihiienichne obgruntuvannia rehlamentiv bezpechnoho zastosuvannia suchasnykh khimichnykh zasobiv zakhystu yablunevykh sadiv. (Doctoral dissertation). Instytut hihiieny ta medychnoi ekolohii im. O.M. Marzieieva, Kyiv.

MalhatF.M.(2017). BICYCLOPYRONE(295).CentralAgricultural pesticidesLaboratory.Giza,Egypt. 25-55.http://www. fao.org/fileadmin/templates/agphome/documents/Pests_Pesticides/JMPR/Evaluation2017/BICYCLOPYRONE_295_.pdf

Mel’nikov, N.N. (1996). K voprosu o zagryaznenii pochvy` xlororganicheskimi soedineniyami. Agroximiya, 10, $72-74$.

Mel'nikov, N.N., \& Belan, S.R. (1997). Sravnitel’naya opasnost' zagryazneniya pochvy` gerbicidami - proizvodny`mi simm-triazinov i nekotory`x drugix shestichlenny`x geterociklicheskix soedinenij . Agroximiya, 2, 66-67.

National Pesticide Information Center [NPIC]. OSU Extension Pesticide Properties Database. http://npic.orst.edu/ ingred/ppdmove.htm

Papa E., Castiglioni S., Gramatica P., Dukhovny V., Kayumov O. and Calamari D. (2004). Screening the leaching tendency of pesticides applied in Amu Darya Basin (Uzbekistan) Water Research, (38), 3485-3494. https://doi.org/10.1016/j. watres.2004.04.053

Pesticide Properties Data Base [PPDB]. https://sitem.herts.ac.uk/aeru/ppdb/en/atoz.htm

Pesticide Properties Data Base [PPDB]. Amicarbazone. https://sitem.herts.ac.uk/aeru/ppdb/en/ Reports/1159.htm

Pesticide Properties Data Base [PPDB]. Bicyclopyrone. http://sitem.herts.ac.uk/aeru/ppdb/en/ Reports/1652.htm

Pesticide Properties Data Base [PPDB]. Pydiflumentonfen. http://sitem.herts.ac.uk/aeru/ppdb/en/Reports/3086.htm

Pestytsydy. Klasyfikatsiia za stupenem nebezpechnosti: DSanPiN 8.8.1.002-98 (2000). Zb. Vazhlyvykh ofitsiinykh materialiv z sanitarnykh i protyepidemichnykh pytan. 9(1), 249-266.

Public release summary on the evaluation of the new product Amitron 700WG Herbicide (2018), 46. https://apvma. gov.au/node/29506

Public release summary on the evaluation of the new active bicyclopyrone in the product Talinor Herbicide. (2017), 62. https://apvma.gov.au/sites/default/files/publication/26736-prs-bicyclopyrone-talinor-herbicide.pdf

Public release summary on the evaluation of pydiflumetofen in the product Miravis Fungicide (2018), 60. https:// apvma.gov.au/node/29011

US EPA-Pesticides. Amicarbazone: HED Human Health Risk Assessment for New Food Use Herbicide on Field Corn (2005), 11-12.

https://archive.epa.gov/pesticides/chemicalsearch/chemical/foia/web/pdf/114004/114004-2005-08-10a.pdf

Vavrinevich, O.P., Omel'chuk, S. T., \& Bardov, V. G. (2014). Toksikologo-gigienichna oczinka zastosuvannya fungicidiv klasu etilen-bis-ditiokarbamativ v suchasnix texnologiyax ximichnogo zaxistu sil's'kogospodars'kix kul`tur. Visnik VDNZU «Ukraïns `ka medichna stomatologichna akademiya», 14(1), 43-48.

Vogue, P.A., Kerle E. A., Jenkins, J.J. (1994). OSU Extension Pesticide Properties Database; National pesticide information center. http://npic.orst.edu/ingred/ppdmove.htm 


\section{ПРОГНОЗИРОВАНИЕ СТЕПЕНИ}

ОПАСНОСТИ ЗАГРЯЗНЕНИЯ ПОЧВЫ, ПОДЗЕМНЫХ И ПОВЕРХНОСТНЫХ

\section{ВОДОИСТОЧНИКОВ ПЕСТИЦИДАМИ}

ИЗ КЛАССОВ ТРИАЗОЛОНОВ, ТРИКЕТОНОВ И КАРБОКСАМИДОВ В ЗАВИСИМОСТИ ОТ ПОЧВЕННО-
КЛИМАТИЧЕСКИХ УСЛОВИЙ

\section{Мартиянова Юлия, Коршун Мария}

\begin{abstract}
Кафедра гигиены и экологии № 3, НМУ имени А.А. Богомольца, Киев, Украина.
\end{abstract}

Аннотация. Доминирующее место в борьбе с вредителями, сорняками и болезнями растений занимают химические средства защиты, использование которых обеспечивает получение высоких урожаев сельскохозяйственных культур. В то же время, наряду с высоким экономическим эффектом, существует потенциальная опасность широкого применения пестицидов, обусловленная их токсичностью для живых организмов, в частности млекопитающих, способностью накапливаться в почве, мигрировать в контактирующие с ними среды и, в конце концов, поступать в организм человека преимущественно перорально с пищевыми продуктами и питьевой водой. Целью нашего исследования является гигиеническая оценка потенциальной опасности загрязнения почвы и миграции в системе «почва - подземные и поверхностные источники водоснабжения» трех новых пестицидов из различных химических классов в широком диапазоне почвенно-климатических условий. Методы. Объектами исследования являются устойчивость, экотоксикологическая опасность и миграционная способность двух гербицидов: амикарбазона из химического класса триазолонових соединений и бициклопирона из класса трикетонов, и фунгицида пидифлуметофена из класса карбоксамидов. На основе данных о физико-химических свойствах, стабильности в почве, а также параметрах токсикометрии была проведена оценка опасности изучаемых веществ в системе «почва-вода», для чего была определена экотоксикологическая опасность (экотокс); оценена вероятность миграции пестицидов из почвы в подземные воды в соответствии с константой сорбции органическим углеродом $\left(K_{\text {ос }}\right)$, скрининговым индексом вымывания LIX,
FORECASTING THE DEGREE

OF POLLUTION IN SOIL,

UNDERGROUND AND SURFACE WATER

SOURCES BY PESTICIDES FROM

THE TRIAZOLONES, TRIKETONES

AND CARBOXAMIDES CLASSES IN

A WIDE RANGE IN SOIL - CLIMATIC CONDITIONS

\section{Martiianova Yuliia, Korshun Mariia}

Hygiene and ecology department

n.3. National Medical University by

O.O. Bogomolets, Kyiv, Ukraine

Abstract. The dominant position in a battle with pests, weeds and plants' diseases is occupied by chemical sprays, the usage of which ensures high yields of crops. However, along with high economic benefit, there is a potential risk of widespread use of pesticides due to their toxicity to living organisms, including mammals, and the ability to accumulate in soils, migrate in contacting its protection and eventually come into the body mainly with food and drinking water. The aim of our study is to hygienically assess the potential risk of soil contamination and migration in the system «soil-underground and surface water sources» of three new pesticides from different chemical classes in a wide range of soil and climatic conditions. Methods. The objects of the study were the stability, ecotoxicological hazard and migration ability of two herbicides: amicarbazone from the chemical class of triazolinone compounds and bicyclopyrone from the class of tricetones, and the fungicide pydiflumetofen from the class of carboxamide. Based on data on physicochemical properties, soil stability and toxicometry parameters, the hazard of the investigated substances in the soil-water system was assessed, the ecotoxicological hazard (ecotox) was defined; migration probability was assessed into groundwater using the organic carbon sorption constant $\left(\mathrm{K}_{\mathrm{os}}\right)$, screening leachability index (LIX), groundwater ubiquity score (GUS) and potential contamination index for ground- and river water $\left(\mathrm{LEACH}_{\text {mod }}\right)$.

Results and discussion. It was found that pydiflumetofen is a highly resistant (I class) and low-mobility (IV class according to $\mathrm{K}_{\mathrm{os}}$ ) pesticide in soil, with a wide (from minimum to al- 
индексом потенциального вымывания (GUS) и индексом потенциального загрязнения грунтовых и речных вод $\left(\mathrm{LEACH}_{\text {mod }}\right)$.

Результаты и обсуждение. Установлено, что пидифлуметофен является высокостойким (I класс) и мало мобильным (IV класс по $\mathrm{K}_{\text {ос }}$ ) в почве пестицидом, с широким (от минимального до почти максимального) потенциалом выщелачивания по скрининговому индексу LIX, обладающим от очень низкой до высокой способностью к вымыванию в соответствии с индексам GUS (от V до II класса) и $\mathrm{LEACH}_{\text {mod }}$ (от III до I класса). Амикарбазон является стойким (II класс), мобильным (II класс по $\mathrm{K}_{\text {ос }}$ ) и вымывным по LIX (практически в любых почвенно-климатических условиях) пестицидом с высокой (I класс) по $\mathrm{LEACH}_{\text {mod }}$ и от низкой (IV класс) до очень высокой (I класс) по GUS способностью к выщелачиванию. Бициклопирон - высокостойкий (I класс) в лабораторных и стойкий (II класс) в полевых опытах; по $\mathrm{K}_{\text {ос }}$ является от очень мобильного (I класс) до мало мобильного (IV класс), что обусловило широкий (от 0 до почти 1) потенциал выщелачивания по LIX, высокую (I класс) способность к вымыванию по $\mathrm{LEACH}_{\text {mod }}$ и от очень низкой (V класс) до очень высокой (I класс) вероятность выщелачивания по GUS. Экотоксикологическая опасность исследуемых пестицидов в случае различных почвенно-климатических условий ниже на 1-5 порядков по сравнению с ДДТ; к тому же риск негативного влияния воздействия на наземные биоценозы бициклопирона меньше, чем амикарбазона и пидифлуметофена. Вывод. Исследуемые вещества являются вымываемыми в соответствии со скрининговым индексом LIX и показали высокую вероятность опасного загрязнения поверхностных и грунтовых вод по индексам GUS и LEACH ${ }_{\text {mod; }}$; в то же время в определенных почвенно-климатических условиях пидифлуметофену и бициклопирону присуща низкая, амикарбазону - умеренная способность к вымыванию по индексу GUS. Конечная оценка риска для здоровья человека миграции исследуемых пестицидов в системе «почва-вода» будет дана по результатам исследований их поведения в почвенно-климатических условиях Украины.

Ключевые слова: почва, миграция, пестициды, подземные воды, стабильность. most maximum) leaching potential according to the screening index LIX, which has from very low to high ability to leach according to GUS indices (from V to II class) and $\mathrm{LEACH}_{\text {mod }}$ (from III to I class). Amicarbazone is a stable (II class), mobile (II class according to $\mathrm{K}_{\text {os }}$ ) and washable according to LIX (practically in any soil and climatic conditions) pesticide with high (I class) according to $\mathrm{LEACH}_{\text {mod }}$ and from low (IV class) to very high (I class) on GUS ability to leach. Bicyclopyrone - highly resistant (I class) in laboratory and stable (II class) in field experiments; $\mathrm{K}_{\mathrm{os}}$ is from very mobile (I class) to low mobile (IV class), which led to a wide (from 0 to almost 1 ) leaching potential for LIX, high (I class) ability to leach according to $\mathrm{LEACH}_{\text {mod }}$ and from very low (V class) to a very high (I class) probability of leaching by GUS. The ecotoxicological danger of the studied pesticides in different soil and under different climatic conditions is lower by $1-5$ orders of magnitude in comparison with DDT; in addition, the risk of adverse effects on terrestrial biocenoses of bicyclopyrone is lower than that of amicarbazone and pydiflumetofen. Conclusion. The test substances are washable for screening index LIX and showed a high probability of dangerous pollution of surface and ground water by indexes GUS and $\mathrm{LEACH}_{\text {mod }}$, although in certain soil and under certain climatic conditions pydiflumetofen and bicyclopyrone inherent low amicarbazone - moderate capacity for leaching index GUS. The final assessment of the risk to human health of migration of the studied pesticides in the «soil-water» system will be provided based on the results of studies of their behavior in soil and climatic conditions of Ukraine.

Key words: soil, migration, pesticides, groundwater, stability. 